\title{
Could Serum Endocan Be a Vascular Endothelial Marker in Relapsing-Remitting Multiple Sclerosis?
}

\author{
Serum Endocan Düzeyleri Relapsing-Remitting Multipl Sklerozda Bir Vasküler Belirteç \\ Olabilir mi?
}

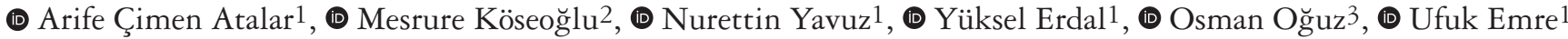
1 University of Health Sciences Turkey, Istanbul Training and Research Hospital, Clinic of Neurology, Istanbul, Turkey 2University of Health Sciences Turkey, Istanbul Bakirkoy Prof. Dr. Mazhar Osman Mental Health and Nervous Diseases Training and

Research Hospital, Clinic of Neurology, Istanbul, Turkey

3University of Health Sciences Turkey, Istanbul Training and Research Hospital, Clinic of Biochemistry, Istanbul, Turkey

\begin{abstract}
Objective: Multiple sclerosis (MS) is a chronic degenerative and inflammatory disease leading to axonal damage and demyelination in the central nervous system. Although the pathogenesis is still controversial, it is accepted that there is an immune-mediated inflammatory response. Endothelial cell specific molecule- 1 (ESM-1) (endocan) is expressed by endothelial cells under the control of cytokines, and increases in inflammatory processes involving the vascular endothelium. In this study, we aimed to compare serum endocan levels along with other hematologic inflammatory markers [such as C-reactive protein (CRP) and erythrocyte sedimentation rate (ESR)] in patients with relapsing-remitting MS (RRMS) and healthy controls. We also aimed at investigating the role of vascular endothelial dysfunction in RRMS.

Materials and Methods: We enrolled 64 patients with RRMS in the remission period, and 37 healthy controls in the study. We investigated hematologic parameters (ESR, CRP) and serum ESM-1 levels by enzyme-linked immunosorbent assay. Results were compared between two groups statistically.

Results: The CRP and ESR had no significant difference between patients and controls ( $\mathrm{p}=0.861$ and $\mathrm{p}=0.76$ respectively). Serum endocan levels of the patient group were significantly higher than the healthy controls $(\mathrm{p}=0.045)$. RRMS patients with or without treatment and comorbid diseases showed no significant difference in serum endocan levels ( $\mathrm{p}=0.565$ and $\mathrm{p}=0.169$ respectively). The predictive value of endocan was $62.0 \%$, cut-off value was $9124.7326 \mathrm{pg} / 1$, sensitivity was $68.8 \%$, and specificity was $54.1 \%$.

Conclusion: We demonstrated higher serum endocan levels in patients with RRMS in remission period, confirming the role of vascular inflammation. Further studies including larger patient cohorts are needed to support our results.

Keywords: Endocan, ESM-1, multiple sclerosis, biomarker, inflammation

$\ddot{\mathbf{O} z}$

Amaç: Multipl skleroz (MS), santral sinir sisteminde demiyelinizasyon ve aksonal hasara yol açan kronik dejeneratif ve enflamatuvar bir hastalıktır. Patogenezi halen tartışmalı olsa da, altta yatan immün aracılıklı bir enflamatuvar yanıtın varlığı kabul edilmektedir. Endotelyal hücre spesifik molekül-1 (ESM-1) (endocan), endotel hücrelerinden sitokinlerin kontrolü altında salınan ve özellikle vasküler endoteli içeren enflamasyon esnasında salınımı artan bir moleküldür. Bu çalışmada serum endocan düzeyleri ve diğer hematolojik enflamasyon belirteçleri olan C-reaktif protein (CRP) ve eritrosit sedimentasyon hızı (ESR) seviyelerinin, relapsingremitting MS (RRMS) ve sağlıklı kontroller arasında kıyaslanarak, RRMS de vasküler endotelyal disfonksiyonun rolünün araştırılması amaçlanmıştır.

Gereç ve Yöntem: Çalısmaya remisyon evresinde olan 64 RRMS hastası ve 37 sağlıklı kontrol dahil edildi. Hematolojik parametreler (ESR ve CRP) ve serum ESM-1 seviyeleri enzim-aracılıklı immünoabsorbsiyon yöntemi ile çalışıldı. Sonuçlar iki grup arasında istatistiksel olarak kıyaslandı.

Bulgular: Hasta ve kontrol grupları arasında CRP ve ESR bakımından anlamlı bir fark bulunamadı (sırasıyla; $\mathrm{p}=0,861$ ve $\mathrm{p}=0,76$ ). Hasta grubunun serum endocan seviyeleri sağlıklı gruba oranla anlamlı düzeyde yükselmişti $(\mathrm{p}=0,045)$. Tedavi almakta olan ve almayan, ile komorbid hastalığ olan ve olmayan hasta grupları arasında serum endocan seviyeleri bakımından anlamlı farklılık bulunamadı (sırasıyla; $p=0,565, p=0,169$ ). Serum endocan seviyelerinin prediktif değeri $\% 62,0$ eşik değeri 9124,7326 pg/l, sensitivitesi $\% 68,8$ ve spesifitesi $\% 54,1$ olarak bulundu.
\end{abstract}

Address for Correspondence/Yazışma Adresi: Arife Çimen Atalar MD, University of Health Sciences Turkey, Istanbul Training and Research Hospital, Clinic of Neurology, Istanbul, Turkey

Phone: +90 5338141817 E-mail: cimenatalar@yahoo.com.tr ORCID: orcid.org/0000-0003-0328-9607

Received/Geliș Tarihi: 16.02.2020 Accepted/Kabul Tarihi: 07.06.2021

${ }^{\circ}$ Copyright 2021 by Turkish Neurological Society

Turkish Journal of Neurology published by Galenos Publishing House. 


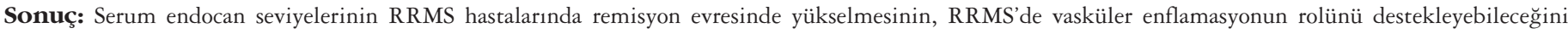
düşünmekteyiz. Bu konuda daha geniş hasta sayıları ile yapılacak çalışmalara ihtiyaç bulunmaktadır.

Anahtar Kelimeler: Endocan, ESM-1, multipl skleroz, biomarker, enflamasyon

\section{Introduction}

Multiple sclerosis (MS) is a chronic degenerative and inflammatory disease leading to axonal damage and demyelination in the central nervous system $(1,2)$. With accumulating evidence, the role of inflammation in various neurodegenerative diseases, including MS, is being recognized (3). Recent studies demonstrated that there is an immune-mediated inflammatory response with the infiltration of activated monocytes, T-cells and B-cells in regions of white matter leading to myelin destruction, followed by axonal damage and atrophy. Demyelinating plaques (the pathologic hallmark of MS) were shown to be strongly related with immunemediated response $(4,5,6,7)$.

No specific antigen triggering this inflammatory process has been identified yet (8). A hypothesis stipulates that there is a remodeling of the blood brain barrier (BBB) in the pathological course of the disease leading to vascular inflammation, secondary ischemia and subsequent demyelination triggered by activated CD4 + T-lymphocytes and the cytokines they release $(9,10,11)$. These activated T-lymphocytes might damage the BBB leading to a vascular endothelial dysfunction $(11,12)$. Abnormalities of the $\mathrm{BBB}$ and vascular endothelial dysfunction is of paramount importance in the pathophysiology of MS, and is considered to be an early feature in the pathological course of the disease. Numerous clinical trials and medical therapies are being developed targeting the vascular endothelial dysfunction and repair of the $\operatorname{BBB}(11,12)$.

Endothelial cell specific molecule-1 [(ESM-1) endocan] is a dermatan sulfate proteoglycan molecule expressed by endothelial cells in various epithelia and adipocytes of the body under the control of a number of cytokines and growth factors, and increases in inflammatory processes of the vascular endothelium $(13,14,15,16)$. It is involved in cell adhesion, migration, proliferation, neovascularization and overexpressed in situations like vascular endothelial damage as well as regulated by inflammatory cytokines and proangiogenic stimuli (17). The levels of endocan elevate in many systemic diseases like diabetes mellitus, chronic kidney disease, pulmonary diseases, hypertension, sepsis, various cancer types (18) and neurological diseases like sleep apnea syndrome (19), migraine (20), and restless leg syndrome (RLS) (21). Endocan is generally accepted as a biomarker of endothelial inflammation and can be useful in practice along with other inflammatory cytokines $(17,22,23)$. Since pathological evidence suggests that inflammation drives tissue injury at all stages of MS, it might also have a role in MS pathophysiology.

To our knowledge, there are no studies investigating the serum endocan levels in MS and/or the relationship of endocan with the pathophysiology of MS.

In this study, we aimed at studying the basic hematologic parameters of inflammation such as erythrocyte sedimentation rate (ESR), C-reactive protein (CRP) and serum endocan levels in patients with relapsing-remitting MS (RRMS) in the remission phase. We also sought to investigate the role of vascular endothelial dysfunction in MS and assess its usefulness as an early biomarker in these patients.

\section{Materials and Methods}

\section{Patient Selection}

This prospective study was conducted in two long-established MS centers; Istanbul Training and Research Hospital, and Bakirkoy Education and Research Hospital for Psychiatry, Neurology, and Neurosurgery between January 2018 and January 2019. Ethical approval for this study was obtained by the Health Sciences University Turkey, Istanbul Training and Research Hospital Ethics Committee (6.04.2018/decision number: 1222). All participants were fully informed, and gave their consent prior to participation in the study.

\section{Inclusion Criteria}

Patients were enrolled according to the following criteria: Age between 18-75, having a diagnosis of RRMS according to the 2017 McDonald Diagnostic criteria for MS (24), being in the remission period at the time of inclusion, having a minimum of one-year follow-up period, having a minimum of one cranial magnetic resonance imagining (MRI) performed with and without contrast, and given an informed consent to participate in the study.

\section{Exclusion Criteria}

We excluded patients with any chronic or acute infection, other immunological and metabolic diseases, any type of cancer, diabetes mellitus, cardiovascular diseases and hypertension, acute or chronic kidney disease, having a diagnosis of RLS or sleep apnea syndrome which may affect serum endocan levels. We also excluded patients with the following conditions from our study: pregnancy, lactation, asthma, pulmonary diseases, Parkinson's or any type of dementia.

\section{Patient Assessment}

We enrolled 110 RRMS patients during the remission phase and 60 healthy controls to the study. After exclusion (46 RRMS patients and 23 healthy controls were excluded), we included 64 RRMS patients followed-up in our MS centers and 37 volunteered healthy controls (medical students, patients relatives) in our study. Each participant was examined systematically and a detailed neurological examination was performed. A structured questionnaire was applied to all participants and the following data were recorded; demographic characteristics, past medical history, family history, age of disease onset, follow-up time, disease duration, number of attacks per year, latest attack types [classified as brainstem, motor and/or sensory, visual (optic neuritis), myelitis], comorbid diseases, expanded disability status scale (EDSS) score (for evaluating disability in MS), and current medical therapy.

Cranial, thoracic and cervical spinal MRI scans that were performed for definite diagnosis of MS using either 1.5-Tesla or 
3-Tesla MRI (images obtained with and without contrast agents in several sequences; coronal, axial and sagittal planes) were retrospectively evaluated by experienced neuroradiologists.

Patients that have not experienced any attack and remained neurologically stable with a minimum of 30 days prior to blood sampling were accepted as being in "remission" period (25).

Finally, blood samples were collected during the remission period of the patient group. Moreover, the ESR, CRP and endocan levels were assessed from the serum of participants.

\section{Blood Analysis}

Complete blood count analysis was performed using a Sysmex XT 1800i device (Roche-2011, Kobe, Japan). Blood sampling was performed between 9.00 a.m. and 10.30 a.m., and collected in dipotassium- ethylenediaminetetraacetic acid tubes. Samples were analyzed within $30 \mathrm{~min}$ to $1 \mathrm{~h}$ after collection.

CRP levels were studied using the turbidimetric method (Toshiba ACCUTE TBA-40FR; Toshiba Medical Systems, Tokyo, Japan). The ESR titers were obtained by spectrophotometric assay (Alifax Test 1, THl $950 \mathrm{~nm}$ ).

\section{Enzyme-linked Immunosorbent Assay (ELISA)}

Following overnight fasting, venous blood samples (2 $\mathrm{ml})$ were collected into gel tubes between 9:00 a.m. and 10:30 a.m. A 20-min time interval was allowed for coagulation, followed by centrifugation at $1500 \mathrm{x} g$ for $15 \mathrm{~min}$. All samples taken from patients and controls were frozen at $-80{ }^{\circ} \mathrm{C}$ until use. Concentrations of endocan in serum were measured using ELISA kit, according to protocols provided by the manufacturers (Human Endocan ELISA Kit, Elabscience, catalog number: E-EL-H1557, USA). The performance characteristics of this kit was listed as follows; sensitivity: $9.38 \mathrm{pg} / \mathrm{ml}$; detection range: $15.63-1000 \mathrm{pg} /$ $\mathrm{ml}$; repeatability: Intra-assay and inter-essay coefficient of variation is $<10 \%$. Multiskan FC ${ }^{\circledR}$ Microplate Photometer (Thermo Fisher Scientific, Waltham, MA, USA) was used for reading at 450 $\mathrm{nm}$. The results were expressed in picograms per liter $(\mathrm{pg} / \mathrm{l})$. All measurements were performed at the central biochemistry laboratory of the Istanbul Training and Research Hospital by the same biochemist (O.O.).

\section{Statistical Analysis}

Nominal and ordinal variables were described as frequencies. Scale parameters were described as mean and standard deviations. Chi-square test was used for sex differences between groups. All scale parameters were tested for normality using the KolmogorovSmirnov test with Lilliefors correction. Since age was distributed normally, the independent t-test was used for differences between groups. The Mann-Whitney U test was used to analyze differences between groups as endocan levels were not normally distributed. Receiver operating characteristic (ROC) analysis was used to define the cut-off value for endocan levels. A Spearman's correlation analysis was performed to evaluate any correlations between the clinical properties of RRMS and endocan levels. A linear regression analysis was also performed for the EDSS score as the outcome. Age, gender, disease duration, ESR, CRP and endocan levels were considered as independent variables for prediction. All analyses were performed by SPSS 22.0 for windows with $95 \%$ confidence interval. Significance level was set at $\mathrm{p}<0.05$.

\section{Results}

Sixty-four patients with RRMS and thirty-seven healthy volunteers were included to the study. Some clinical and demographic properties of the patients are summarized in Table 1.

The majority of the patients $(59.4 \%)$ had sensory attacks as the most recent of the MS attacks. The attack frequency per year was $40.6 \%$ in the patient group. The median time from the last attack to the time of participation in the study was $112 \pm 3.14$ days. At the time of blood collection, $87.5 \%$ of patients were under disease modifying drug therapy. These included fingolimod $(38.33 \%)$, teriflunomide $(16.66 \%)$, ocrelizumab $(15 \%)$, glatiramer acetate $(11.66 \%)$, Interferon beta 1-b s.c $(6.6 \%)$, dimethyl fumarate (5\%), Interferon beta 1-b I.M (5\%), and Interferon beta 1-a s.c $(1.6 \%)$, respectively. In the patient group, $45.3 \%$ had one or more comorbid diseases [anemia $(n=13)$, hypothyroidism $(n=8)$, osteoporosis $(n=3)$, depression $(n=5)]$. There were no patients with a comorbid systemic disease in the control group, and all were chosen from healthy volunteers.

The mean age of the patient and control groups were $38.33 \pm 1.09$ years and $38.51 \pm 1.04$ years, respectively $(\mathrm{p}>0.05)$. The female/male distribution was $47(74.6 \%) / 16(25.4 \%)$ in the patient group and $12(32.4 \%) / 25(67.6 \%)$ in the control group $(\mathrm{p}>0.05)$. The CRP and ESR titers were not significantly different between patients and controls $(\mathrm{p}=0.861$ and $\mathrm{p}=0.76$ respectively). Serum endocan levels of the patient group were significantly higher than those of healthy controls $(\mathrm{p}=0.045)$ (Figure 1).

When we compared the endocan levels between patients with RRMS (with or without treatment and with or without comorbid

\begin{tabular}{|ll|}
\hline $\begin{array}{l}\text { Table } 1 . \text { Demographic and clinical characteristics of RRMS } \\
\text { patients }\end{array}$ & Patient group ( $\mathrm{n}=64)$ \\
$\begin{array}{l}\text { Clinical and demographic } \\
\text { parameters }\end{array}$ & $30.70 \pm 8.41$ \\
$\begin{array}{l}\text { Age of disease onset, years, } \\
\text { mean } \pm \text { SD }\end{array}$ & $5.02 \pm 4.82$ \\
$\begin{array}{l}\text { Follow-up duration, years, } \\
\text { mean } \pm \text { SD }\end{array}$ & $92.75 \pm 74.58$ \\
$\begin{array}{l}\text { Disease duration, months, } \\
\text { mean } \pm \text { SD }\end{array}$ & $15(23.4)$ \\
$\begin{array}{l}\text { Latest attack types } \mathrm{n}(\%) \\
\text { Visual }\end{array}$ & $38(59.4)$ \\
$\begin{array}{l}\text { Sensory and motor } \\
\text { Myelitis }\end{array}$ & $7(10.9)$ \\
$\begin{array}{l}\text { Brainstem } \\
\text { Number of attacks per year }\end{array}$ & $1 \pm 0.41$ \\
$\begin{array}{l}\text { EDSS (mean } \pm \text { SD) } \\
\text { (minimum-maximum) }\end{array}$ & $2.57 \pm 1.27(1-6.5)$ \\
Treatment & \\
No prophylactic treatment $\mathrm{n}(\%)$ & $8(12.5)$ \\
Comorbid diseases & $56(87.5)$ \\
Yes $\mathrm{n}(\%)$ & $29(45.3)$ \\
No n (\%) & $35(54.7)$ \\
$\begin{array}{l}\text { RRMS: Relapsing-remitting multiple sclerosis, SD: Standard deviation, EDSS: } \\
\text { Expanded disability status scale }\end{array}$ & \\
\hline
\end{tabular}


diseases), there were no significant differences between them $(\mathrm{p}=0.565$ and $\mathrm{p}=0.169$ respectively).

Comparison of CRP, ESR and serum endocan levels between the patient and control groups are shown in Table 2.

We also performed a correlation analysis between the demographic and clinical properties of patients and their endocan levels. There was no significant correlation between any of the clinical properties of RRMS patients and serum endocan levels $(\mathrm{p}=0.578, \mathrm{r}=0.56$ for sex, $\mathrm{p}=0.918, \mathrm{r}=0.10$ for age, $\mathrm{p}=0.628$, $r=0.62$ for age of disease onset, $p=0.699, r=0.49$ for disease duration and $\mathrm{p}=0.930, \mathrm{r}=0.011$ for follow-up time). The only positive correlation was between the disease duration and EDSS levels as expected for patients with RRMS (correlation coefficient: $0.368, \mathrm{p}=0.003$ ).

Furthermore, we performed linear logistic regression analysis which revealed no correlation between endocan levels and independent variables (age, gender, disease duration, EDSS score, ESR and CRP) (Table 3).

In the ROC analysis to determine the cut-off value of endocan; the predictive value was found at $62.0 \%$. Cut-off value for endocan

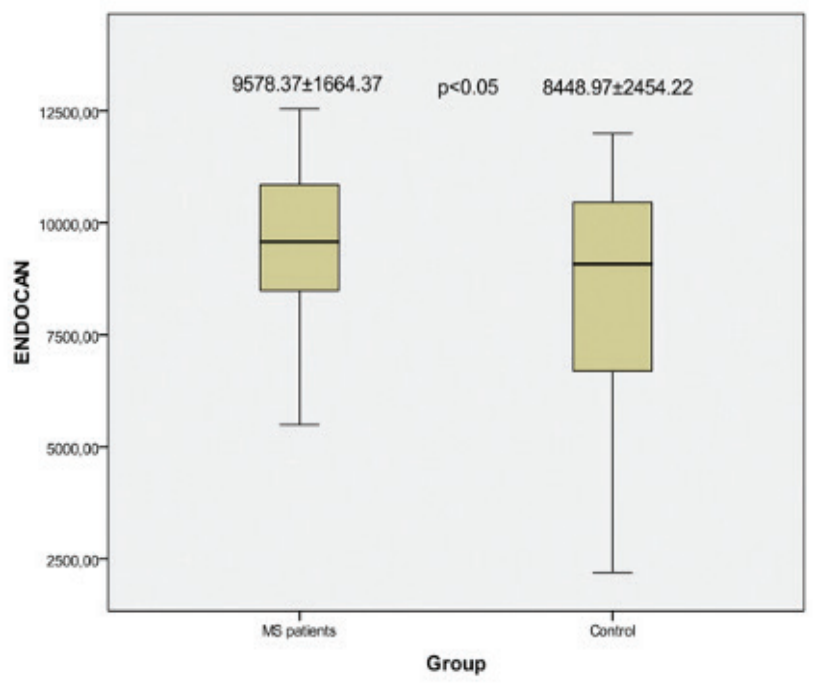

Figure 1. Comparison of ESM-1 (endocan) levels between patient and control groups. The serum ESM-1 levels are expressed in picograms per liter $(\mathrm{pg} / \mathrm{l})$

ESM-1: Endothelial cell specific molecule-1, MS: Multiple sclerosis level was at $9124.7326 \mathrm{pg} / \mathrm{l}$, sensitivity at $68.8 \%$ and specificity at $54.1 \%$ (Figure 2).

\section{Discussion}

The results of this study revealed higher endocan levels in patients with RRMS in the remission period when compared to healthy individuals, thereby demonstrating the role of vascular inflammation in RRMS patients.

Furthermore, the ROC analysis confirmed a sensitivity and specificity value for endocan levels $(68.8 \%$ and $54.1 \%$, respectively) in the diagnosis of RRMS. However, no significant differences were observed for endocan levels among patients with RRMS when compared as with or without treatment, and with or without comorbid diseases $(\mathrm{p}=0.565, \mathrm{p}=0.169$ respectively). In addition, other hematologic markers of inflammation such as ESR and CRP were also similar between patient and control groups.

Since accumulating radiological and pathological evidence show the role of endothelial dysfunction and vascular endothelial inflammation as an early feature of MS, the importance of

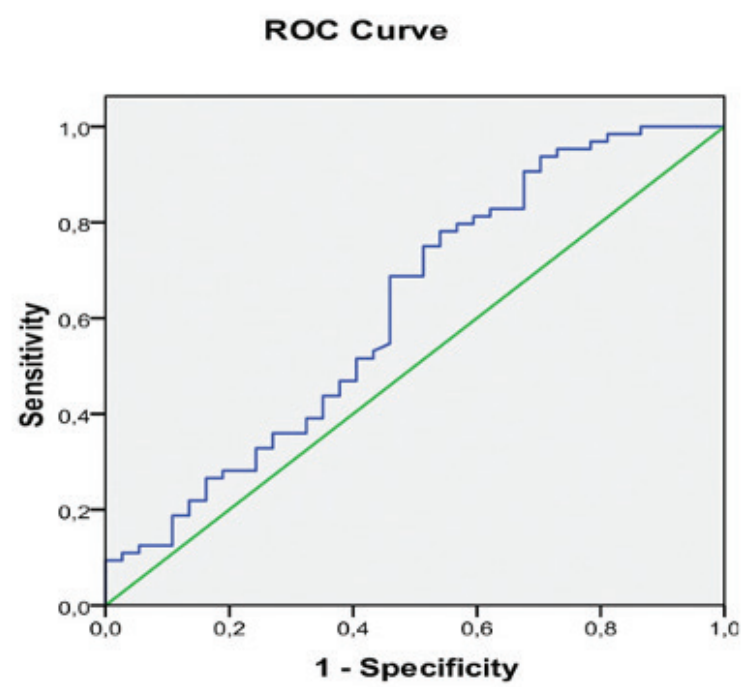

Diagonal segments are produced by ties.

Figure 2. ROC curve analysis of serum ESM-1 levels (pg/l) ROC: Receiver operating characteristic, ESM-1: Endothelial cell specific molecule-1

Table 2. Comparison of CRP, ESR and serum endocan levels between the patient and control groups

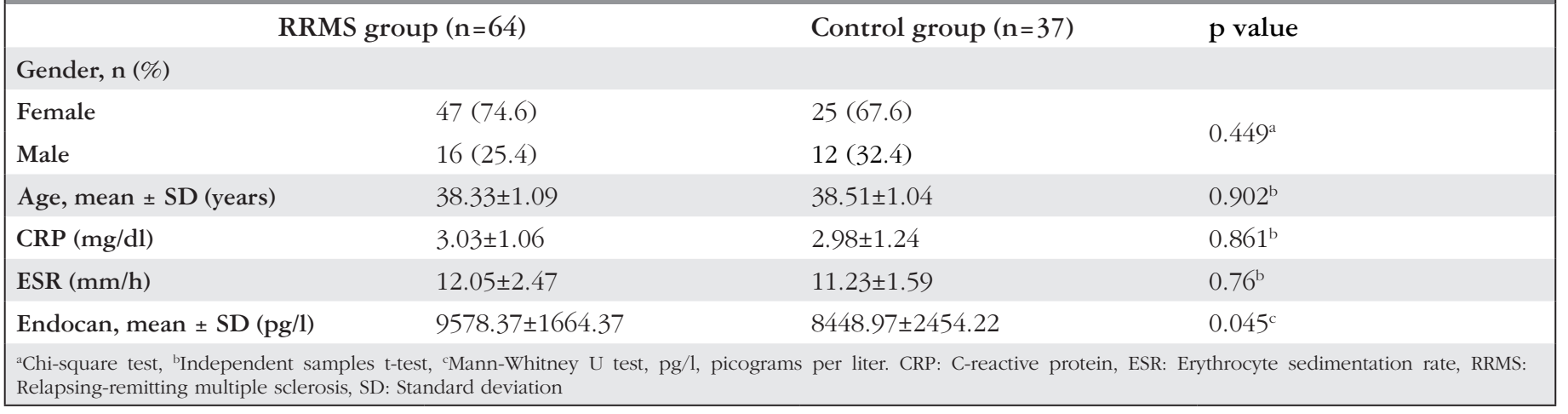


Table 3. Linear logistic regression analysis for serum endocan levels in patients with RRMS

\begin{tabular}{|c|c|c|c|c|c|c|c|}
\hline \multirow[t]{2}{*}{ Group } & \multirow{2}{*}{\multicolumn{2}{|c|}{ Model }} & \multicolumn{2}{|c|}{ Unstandardized coefficients } & \multirow{2}{*}{$\begin{array}{l}\text { Standardized } \\
\text { coefficients } \\
\text { Beta }\end{array}$} & \multirow[t]{2}{*}{$\mathbf{t}$} & \multirow[t]{2}{*}{ Sig* } \\
\hline & & & B & Standard error & & & \\
\hline \multirow{7}{*}{$\begin{array}{l}\text { RRMS } \\
\text { patients }\end{array}$} & \multirow{7}{*}{1} & (Constant) & 11786.127 & 1687.810 & & 6.983 & 0.000 \\
\hline & & Gender & 518.878 & 506.234 & 0.139 & 1.025 & 0.310 \\
\hline & & Age & 33.071 & 28.688 & 0.177 & 1.153 & 0.254 \\
\hline & & Disease duration/months & $-1,845$ & 3.376 & -0.084 & -0.546 & 0.587 \\
\hline & & ESR & -304.224 & 145.585 & -0.290 & -2.090 & 0.041 \\
\hline & & CRP & -89.581 & 172.087 & -0.068 & -0.521 & 0.605 \\
\hline & & EDSS score & -126.913 & 179.871 & -0.099 & -0.706 & 0.483 \\
\hline
\end{tabular}

identifying sensitive biomarkers cannot be overemphasized (26). To our knowledge, this is the first study investigating serum endocan levels as a possible biomarker of endothelial dysfunction in patient with MS. There are a handful of studies investigating other endothelial proinflammatory mediators in MS $(11,27,28)$. Haufschild et al. (26), investigated plasma levels of endotelin-1 [(ET-1); one of the most potent endothelial vasoconstrictor peptides] in the sera of MS patients, and found that ET-1 levels were $224 \%$ higher in patients with MS than in healthy controls. Similarly, in another study by Pache et al. (27), they exhibited elevated plasma ET-1 levels in a cohort of $30 \mathrm{MS}$ patients, thereby supporting the role of endothelial mediators in the pathogenesis of MS. Other endothelial mediators like pentraxin [(PTX-3); which is released from endothelium in response to inflammatory signals] were also found to be elevated in patients with MS. In a study by Wang et al. (9), they found increased levels of plasma PTX-3 in both patients with MS and neuromyelitis optica, and a borderline significant correlation with EDSS scores. This inferred that PTX-3 could be used as a biomarker in MS. In the current study, although serum endocan levels were higher in the RRMS group, there was no correlation between endocan levels and clinical or demographic properties of patients with MS (including the EDSS scores).

There are other studies investigating the role of endocan as a proinflammatory biomarker in other neurological diseases. In a study by Varan et al. (29), the authors analyzed serum endocan levels in 134 participants $[47$ patients with Alzheimer's disease (AD), 42 patients with mild cognitive impairment and 45 controls] and showed higher serum endocan levels in patients with AD than the other groups. They suggested that higher serum endocan levels demonstrate the role of endothelial activation and dysfunction in AD (29). The serum levels of endocan were also investigated in RLS, another common neurological disease. The authors found decreased levels of plasma endocan in a cohort of 31 patients with RLS in a recent study. They hypothesized that endothelial functioning might be preserved in RLS patients and may protect these patients against the risk of atherosclerosis (21).

In our study, we hypothesize that higher endocan levels in serum might be a positive indicator of vascular endothelial inflammation in patients with RRMS even in the remission period. However, the elevated serum endocan levels notwithstanding, we haven't observed any relationship between endocan levels and the demographical or clinical properties of patients with MS (including the EDSS scores which is an indicator of the severity). We believe that higher endocan levels could be a reflection of the vascular inflammation process, an important part of MS pathophysiology. However, with the conflict whether the inflammation in MS is the main driving force of tissue damage in MS, or an amplifying reaction after neurodegeneration, high endocan levels could not be interpreted as an early biomarker.

\section{Study Limitations}

Our study has some limitations. Although we showed that endocan levels are higher in patients with RRMS (which could imply the role of vascular endothelial inflammation in these patients), larger confirmatory studies are needed for secondary progressive MS patients. Moreover, the impact of disease modifying drugs on the endocan levels has not been evaluated. Therefore, clinicians must be cautious while interpreting our results. Lastly, it is probable that vascular endothelial inflammation might be more prompt in the relapsing phase of MS. Since we enrolled patients in the remission phase this could be also create a possible limitation.

Despite our limitations, our study might be clinically relevant as being the first study demonstrating a relationship between MS and serum endocan levels.

\section{Conclusion}

We observed higher serum endocan levels in patients with RRMS during the remission period, thereby confirming the role of vascular inflammation. We believe serum endocan analysis in RRMS patients, might be useful for demonstrating vascular inflammation in RRMS in everyday clinical practice.

Further studies with larger samples especially in the relapse period of RRMS patients are recommended to support our results and highlight the role of endocan levels in pathogenesis of MS.

\section{Acknowledgments}

We thank all our patients and volunteers for their contributions to this study.

\section{Ethics}

Ethics Committee Approval: Ethical approval for this study was obtained by the Health Sciences University Turkey, Istanbul Training and Research Hospital Ethics Committee (6.04.2018/ decision number: 1222). 
Informed Consent: All participants were fully informed, and gave their consent prior to participation in the study.

Peer-review: Externally and internally peer-reviewed.

\section{Authorship Contributions}

Concept: A.Ç.A., M.K., O.O., Design: U.E., A.Ç.A., Data Collection or Processing: N.Y., Y.E., M.K., Analysis or Interpretation: A.Ç.A., O.O., Literature Search: A.Ç.A., Writing: A.Ç.A.

Conflict of Interest: No conflict of interest was declared by the authors.

Financial Disclosure: The authors declared that this study received no financial support.

\section{References}

1. Klotz L, Kuzmanov I, Hucke S, et al. B7-H1 shapes T-cell-mediated brain endothelial cell dysfunction and regional encephalitogenicity in spontaneous CNS autoimmunity. Proc Natl Acad Sci USA 2016;113:E6182-E6191.

2. Scheu S, Ali S, Mann-Nüttel R, et al. Interferon $\beta$-mediated protective functions of microglia in central nervous system autoimmunity. Int J Mol Sci 2019;20:E190.

3. Chitnis T, Weiner HL. CNS inflammation and neurodegeneration. J Clin Invest 2017;127:3577-3587.

4. Bendszus M, Storch-Hagenlocher B. Multiple Sclerosis and Other Demyelinating Diseases, Inflammatory Diseases of the Brain. Springer; 2013, pp. 3-18.

5. Honardoost MA, Kiani-Esfahani A, Ghaedi K, Etemadifar M, Salehi M. miR-326 and miR-26 a, two potential markers for diagnosis of relapse and remission phases in patient with relapsing-remitting multiple sclerosis. Gene 2014;544:128-133.

6. Sánchez-López AL, Ortiz GG, Pacheco-Moises FP, et al. Efficacy of Melatonin on Serum Pro-inflammatory Cytokines and Oxidative Stress Markers in Relapsing Remitting Multiple Sclerosis. Arch Med Res 2018;49:391-398.

7. Howell OW, Reeves CA, Nicholas R, et al. Meningeal inflammation is widespread and linked to cortical pathology in multiple sclerosis. Brain 2011;134:2755-2771.

8. Lemus HN, Warrington AE, Rodriguez M. Multiple Sclerosis: Mechanisms of Disease and Strategies for Myelin and Axonal Repair. Neurol Clin 2018;36:1-11.

9. Wang $\mathrm{H}$, Wang $\mathrm{K}$, Wang $\mathrm{C}$, Zhong X, Qiu W, Hu X. Increased plasma levels of pentraxin 3 in patients with multiple sclerosis and neuromyelitis Mult Scler 2013;19:926-931.

10. Minager A, Wenche JY, Jimenez JJ, Alexander JS. Multiple sclerosis as a vascular disease. Neurological Res 2006;28:230-235.

11. Jankowska-Lech I, Terelak-Borys B, Grabska-Liberek, I, et al. Endothelin-1 Plasma Levels in Multiple Sclerosis Patients: A Possible Factor of Vascular Dysregulation? Med Sci Monit 2015;21:1066-1071.
12. Spencer JI, Bell JS, DeLuca GC. Vascular pathology in multiple sclerosis: reframing pathogenesis around the blood-brain barrier. J Neurol Neurosurg Psychiatry 2018;89:42-52.

13. Bechard D, Meignin V, Scherpereel A, et al. Characterization of the secreted form of endothelial-cell-specific molecule 1 by specific monoclonal antibodies. J Vasc Res 2000;37:417-425.

14. Janke J, Engeli S, Gorzelniak K, et al. Adipose tissue and circulating endothelial cell specific molecule-1 in human obesity. Horm Metab Res 2006;38:28-33.

15. Wellner M, Herse F, Janke J, et al. Endothelial cell specificmolecule-1 - a newly identified protein in adipocytes. Horm Metab Res 2003;35:217-221.

16. Bechard D, Scherpereel A, Hammad H, et al. Human endothelial-cell specific molecule-1 binds directly to the integrin CD11a/CD18 (LFA1) and blocks binding to intercellular adhesion molecule- 1. J Immunol 2001;167:3099-3106.

17. Tariket S, Sut C, Arthaud CA, et al. Modeling the effect of platelet concentrate supernatants on endothelial cells: focus on endocan/ESM-1. Transfusion 2018;58:439-445.

18. Balta S, Mikhailidis DP, Demirkol S, et al. Endocan: A novel inflammatory indicator in cardiovascular disease? Atherosclerosis 2015;243:339-443.

19. Bingol Z, Kose M, Piht1l A, et al. Serum endothelial cell specific molecule-1 (endocan) levels in patients with obstructive sleep apnea. Biomark Med 2016;10:177-184.

20. Yücel M, Kotan D, Gurol Çiftçi G, et al. Serum levels of endocan, claudin-5 and cytokines in migraine. Eur Rev Med Pharmacol Sci 2016;20:930-936.

21. Celik K, Cikrikcioglu MA, Halac G, et al. Serum endocan levels in women with restless legs syndrome. Neuropsychiatr Dis Treat 2015;19:2919-2925.

22. Zhang SM, Zuo L, Zhou Q, et al. Expression and distribution of endocan in human tissues. Biotech Histochem 2012;87:172-178.

23. Delehedde M, Devenyns L, Maurage CA, Vivès RR. Endocan in cancers: a lesson from a circulating dermatan sulfate proteoglycan. Int J Cell Biol $2013 ; 705027$.

24. Thompson AJ, Banwell BL, Barkhof F, et al. Diagnosis of multiple sclerosis: 2017 revisions of the McDonald criteria. Lancet Neurol 2017;17:162-173.

25. Compston A, Coles A. Multiple sclerosis. Lancet 2008;37:1502-1517.

26. Haufschild T, Shaw SG, Kesselring J, Flammer J. Increased endothelin-1 plasma levels in patients with multiple sclerosis. J Neuroophthalmol 2001;21:37-38.

27. Pache M, Kaiser HJ, Akhalbedashvili N, et al. Extraocular blood flow and endothelin-1 plasma levels in patients with multiple sclerosis. Eur Neurology 2003;49:164-168.

28. Yun JW, Cvek U, Kilgore PCSR, et al. Neurolymphatic biomarkers of brain endothelial inflammatory activation: Implications for multiple sclerosis diagnosis. Life Sci 2019;229:116-123.

29. Varan HD, Guner G, Kizilarslanoglu MC, et al. Higher Serum Endocan Level Is Associated with Alzheimer Disease. Dement Geriatr Cogn Disord 2017;44:303-310. 